\title{
The Superiority of Women in the Seventeenth Century*
}

ABSTRACT: Early feminist or pro-woman works often combine the claim that the rational souls of men and women are the same with an argument for the superiority of women. This article considers two such works, Lucrezia Marinella's The Nobility and Excellence of Women and the Defects and Vices of Men (Venice, I60I [I999]) and Marguerite Buffet's In Praise of Illustrious Learned Women, both Ancient and Modern (Paris, I668), in order to show the continuities and distinctive features of feminist arguments for superiority, to emphasize the differences in the conceptions of reason and physiology that distinguish them, and to demonstrate that claims of superiority persisted even as those defending women's worth began to adopt egalitarian positions.

KEYWORDS: Buffet, Marinella, superiority of women, equality, sexual difference

\section{Introduction}

Accounts of the history of feminist philosophy often treat the claims and arguments of those writing before the eighteenth century as a kind of prehistory to the undeniably important development of a conception of women's rights in the I790s, and describe those promoting the worth of women as pro-woman writers rather than as feminists (see, for example, King I991: 237; Gottlieb I997: 282; see Kelly $\mathrm{I} 982$ for an early dissenting view). But the history of arguments for women's equality is longer and more complex than those accounts imply. It is a history that includes elements worked out in the tradition of the querelle des femmes, a debate about the nature, worth, and capacities of women that played out in Europe from the medieval to the early modern period. Those writing pro-woman contributions to the debate (both men and women) usually argued for the superior worth or dignity of women (see Angenot I977 and Jordan I990). They did so in response to misogynist works, rejecting claims of masculine superiority but often adopting the language, structure, and rhetorical norms of those works. These features sometimes obscure the philosophical interest of the pro-woman arguments. My aim in this paper is to examine one element of the

\footnotetext{
* This article is the ninth in a special series of commissioned articles on women in the history of philosophy. The eighth article 'The Moral Philosophy of Maria Montessori', by Patrick Frierson, appeared in Volume 7, Issue 2, pp. I33-54.

For philosophical and philological help I would like to thank Martina Reuter, Charlotte Sabourin, Lara HarwoodVentura, and the anonymous reviewers of this journal. I am grateful for the support of the Social Sciences and Humanities Research Council of Canada.
} 
debate in the seventeenth century that merits the attention of those interested in the history of feminism and the history of equality more generally: a distinction between a conception of equality as metaphysical and a conception of it as practical. The former is grounded in claims of identical or shared rationality, where the latter relies on theories of embodiment, in particular, of sexual difference.

This distinction emerges from a tension found in many pro-woman works of the querelle between the claim that the sexes share a rational soul that confers equality on them and the assertion of the superiority of women (some scholars have attempted to reduce this tension by suggesting that claims of superiority are covert claims of equality [see, e.g., Ducharme 2003: 333]). We might wonder why those defending the worth of women did not rest content with arguments for the equality claim and what they sought to gain by introducing arguments for the superiority of women. My contention is that for many of those involved in the debate acknowledging equality of reason was sufficient only to demonstrate a kind of equality-in-principle-what I am calling metaphysical equality. Arguments for the superiority of women were used to establish a moral claim to dignity, liberty, education, and ultimately citizenship for women-and so to begin to gain for them equality in practice.

I consider the arguments for the superiority of women made by two seventeenth-century women. The first is the Venetian Lucrezia Marinella (I57II653), who published La nobiltà et l'eccellenza delle donne co'diffetti et mancamenti de gli uomini (The Nobility and Excellence of Women and the Defects and Vices of Men) in Venice in I600 and revised and expanded it for a second edition in I60I. Marinella was a prolific author of polemical treatises, lyric and narrative poetry, and devotional literature who was connected to the intellectual life of the Venetian republic through the second Venetian academy (Kolsky 200I: 976). The second is Marguerite Buffet (d. I680), who published a work in two parts in Paris in I668, entitled Nouvelles observations sur la langue française, Où il est traitté des termes anciens \&o inusitez, \& du bel usage des mots nouveaux, avec les Éloges des Illustres Sçavantes, tant Anciennes que Modernes (New observations on the French language, in which are discussed ancient and unusual terms, and the appropriate use of new words, with In Praise of Illustrious Learned Women, both Ancient and Modern). The first part, as the title suggests, is a work of French grammar; the second part (with the short title Traitté sur les Eloges des Illustres Sçavantes, Anciennes \& Modernes), which concerns us here, is a polemical treatise on the worth of women. Very little is known of Buffet's life, and the Nouvelles observations is the only extant work attributed to her, but she was described in her time as a grammarian or a philologist and is supposed to have taught the arts of speaking and writing well on all subjects (Ducharme 2003: 332). The Eloges has been described as 'a list of women worthies' (Harth I992: 29), and while that is not untrue, it fails to do justice to the philosophical interest of the work, and its defense of women as a sex (by 'women as a sex' I mean to emphasize that, in offering a defense of the worth of women based on their status as rational beings and on their physiology, Buffet, like Marinella, is arguing for the worth of all women, rather than making an exception of an elite class of women, as in some pro-woman works). 
I have chosen to compare Marinella and Buffet in order to demonstrate that the argument for the superiority of women was both widespread in Europe and enduring in the seventeenth century. That argument is characterized by two fundamental claims: that reason is the same in both sexes and that women are nonetheless superior to men because of certain features of their physiology. There is no evidence that Buffet's argument was directly influenced by Marinella's and no reason to assume so: Marinella does not appear in the list of praiseworthy women appended to Buffet's treatise, and they were active in different milieux and at different times. That is, in part, the point: the continuity between their arguments is to be explained, I hypothesize, not by influence from one to the other but by the advantages of the structure of the argument in the context of the seventeenth century.

There are different iterations of the argument that women are superior to men though no different from them in rational capacity. Marinella argues that female physiology, because it is colder, produces more temperate desires, with beneficial effects on both the intellect and the morals of women, whereas Buffet points to anatomical features of the female body that she suggests produce livelier spirits and thus contribute to women's intellectual and moral superiority. Their formulations of the argument for the worth of women show that the particular qualities of the body that were supposed to ground the superiority of women varied—and certainly differed from contemporary notions of sexual difference. In emphasizing that they both argue for the sameness of rational soul as consistent with the superiority of women while appealing to different features of the sexed body, I aim to show that the idea that women are metaphysically equal but practically superior to men had both an enduring core and variant forms.

The aims of this paper are: First, to contribute to the project of enriching and diversifying the history of philosophy by highlighting the work of two seventeenth-century women (Lucrezia Marinella and Marguerite Buffet), situating them in their historical context; the particular aim is to deepen our understanding of the history of feminist philosophy. Second, this paper aims to add to our understanding of the history of the concept of equality. Focusing on Marinella's and Buffet's arguments for the superiority of women, I aim to show some of the complexity of the history of equality between the sexes by drawing out the distinction between metaphysical equality (or equality of nature) and practical equality. My third aim is to show that, in the arguments examined here, metaphysical equality has its ground in the metaphysics of reason, while practical equality relies on the metaphysics of embodiment-in particular, bodily sexual difference. Of special interest is the emphasis pro-woman writers in the seventeenth century placed on the differences of temperature, blood, humors, and spirits that they believed distinguished the sexes, rather than on differences associated with conception, gestation, or childbirth.

\section{Background}

Both Marinella and Buffet defended the worth of women in polemical treatises. These were popular works, intended for an educated but nonacademic audience. For that reason they have not often been considered of philosophical significance. 
But if we are interested in the history of feminist philosophy, we must consider the intellectual contexts in which women were able to engage and those genres in which they were allowed to publish. The dialogues, polemics, poetry, and letters of renaissance and early modern authors (men as well as women) are rich sources of philosophical debate.

Polemics in favor of women usually began with a statement of the identity of the rational soul in men and women (often representing the claim as uncontentious and widely accepted) before moving on to argue for the superiority of women on other grounds. Two influential formulations of the claim were published in 1528 . One was in Henricus Cornelius Agrippa's treatise De nobilitate et praecellentia foeminei sexus (Declamation on the Nobility and Preeminence of the Female Sex): '[God] has attributed to both man and woman an identical soul, which sexual difference does not at all affect. Woman has been allotted the same intelligence, reason, and power of speech as man and tends to the same end he does, that is, happiness, where there will be no restriction by sex' (Agrippa[I 529] I996: 43). ${ }^{\text {I }}$ The other was in the third book of Baldassare Castiglione's dialogue Il libro del Cortegiano (The Book of the Courtier) where the point is expressed in natural rather than theological terms:

For just as no stone can be more perfectly a stone than another, as regards the essence stone, nor one piece of wood more perfectly wood than another piece-so one man cannot be more perfectly man than another; and consequently the male will not be more perfect than the female as regards their formal substance, because the one and the other are included under the species man, and that in which one differs from another is an accident and is not of the essence. (Castiglione I959: 214) ${ }^{2}$

Pro-woman writers in the sixteenth century, while asserting the sameness of the rational soul in men and women, usually follow that assertion with an argument for the superiority of women. By the seventeenth century, however, some participants in the debate take shared rationality to establish without qualification the equality of the sexes. Marie de Gournay, for example, in her treatise Egalité des hommes et des femmes (Gournay 2002b, first published in Paris in I622) says:

Most of those who take up the cause of women, opposing the arrogant preference for themselves that is asserted by men, give them full value for money, for they redirect the preference to them. For my part, I fly all

\footnotetext{
${ }^{\mathrm{I}}$ 'Eandem vero et masculo et foeminae, ac omnino indifferentem animae formam tribuit, inter quas nulla prorsus sexus est distantia, Eandem ipsa mulier cum viro sortita est mentem, rationem atque sermonem, ad eundem tendit beatitudinis finem, ubi sexus nulla erit exceptio’ (Agrippa [I 529] I990:49).

2 'Come niun sasso po esser più perfettaemente sasso che un altro quanto alla essenzia del sasso, né un legno più perfettamente legno che l'altro, così un omo non po essere più perfettamente omo che l'altro, e conseguentamente non sarà il maschio più perfetto che la femina, quanto alla sustanzia sua formale, perchél'uno e l'altro si comprende sotto la specie dell'omo e quello in che l'uno dall'altro son differenti è cosa accidentale e non essenziale' (Castiglione I 965 : 227). I have left the idiosyncrasies of spelling, punctuation, and accentuation in the French and Italian texts as they were written.
} 
extremes; I am content to make them equal to men, given that nature, too, is as greatly opposed, in this respect, to superiority as to inferiority. (Gournay 2002b: 75$)^{3}$

Aligning herself with nature, Gournay declines to say that women are superior to men and bases her argument for the worth of women on the sameness of the soul. What is new and radical in her position is then not the assertion that women have the same rational soul as men, but the refusal to accompany that assertion with an argument for the superiority of her sex.

The most significant difference philosophically between those who argued for the superiority of women and those who claimed to be content with equality for the sexes was the view they took of the body. Radical egalitarians dismissed the significance of bodily sexual differences (as does, for example, Gournay), but those arguing for the superiority of women usually turned to the evidence of the body and its effects on the soul and on reason. Questions of physiology and the interaction of mind and body were of broad interest, and we might expect that the views of male philosophers and physicians in the same period influenced Marinella and Buffet in their accounts of sexual difference. Marinella assumes a conception of the human soul and its interaction with the body drawn from a combination of contemporary Platonist and Aristotelian sources and the traditions of Hippocratic and Galenic medicine (for an account of the approach of natural science to the question of sex difference in the medieval period, see Cadden I993; in the Renaissance, see MacLean I980).

These sources retained authority later in the seventeenth century; one scholar has noted that 'the urge to re-evaluate women's moral and physical character can be traced to Renaissance humanism, which predated the new philosophy by several centuries' (Schiebinger I989: I65).

But Buffet's philosophical context included representatives of the 'new philosophy'. Descartes, Malebranche, Poulain de la Barre, and others (Jacques Rohault and Marin Cureau de la Chambre among them) were Buffet's near-contemporaries, so it seems probable that her views were influenced by theirs -but there is debate about just what those views were. Descartes's reticence on the subject of sexual difference, his insistence that reason is the same in every person (see Discours de la méthode, I: 'la puissance de bien juger et distinguer le vrai d'avec le faux, qui est proprement ce qu'on nomme le bon sens ou la raison, est naturellement égale en tous les hommes' [Descartes (I637) I954: 40]), together with his dualism, are interpreted by some as a commitment to sexual equality (Schiebinger 1989: 174; Hoffman I977: 45-52). Others have called into question whether Cartesian dualism was sufficient to establish the equality of the sexes (see Lloyd I984: $38-50$; Reuter 20I9). Particularly interesting for my purposes here is the question whether the Cartesian account of the mind allowed for significant

\footnotetext{
3 'La pluspart de ceux qui prennent la cause des femmes, contre cette orgueilleuse preferance que les hommes s'attribuent, leur rendent le change entier: car ils renvoyent la preference vers elles. Quant à moy qui fuis toutes extremitez, je me contente de les esgaler aux hommes: la Nature s'opposant aussi pour ce regard, autant à la superiorité qu'à l'inferiorité' (Gournay 2002a: 295).
} 
differences between the sexes. Descartes may have thought both that the mind has no sex and that the mind is affected by the body when the person is considered as a union of body and mind. So the question of sexual difference becomes empirical and depends on whether there are differences in the ways the bodies of men and women affect their minds (Reuter 2019: 47). Cartesians were divided on this question: Malebranche seemed to believe that the brains of women were different in ways that affected their intellectual abilities (Malebranche [I674] I962: tome I, II. 2. I, 266-67; but see Broad [20I 2: 376] for the claim that Malebranche may not have 'advocated a gendered physiological essentialism'), whereas Poulain de la Barre did not (he says 'le cerveau de celles-cy [i.e., women] est entierement semblable au nôtre'- 'the brain of women resembles ours in every respect' [Poulain de la Barre I673: II 2]).

This debate is not explored here. It is, however, worth noting that Buffet and Marinella were advancing a view that runs parallel to that of Malebranche, according to which, while men and women have the same capacity for reason, their bodies are different in ways that affect their larger intellectual capacities; but they were arguing that those differences amounted to advantages women held over men rather than manifestations of male superiority.

\section{Marinella}

The most influential current of pro-woman writing in the sixteenth century took as self-evident that the souls of men and women must be identical in order for the sexes to be members of the same species (we have seen that both Agrippa and Castiglione, whom I have quoted above, made that point). Marinella herself attributes a version of the claim to Moderata Fonte, altering somewhat a passage from Floridoro (Fonte [I58I] 2006) to read 'And why [would we not expect women to be as capable as men] if their nature is shared, if their substances do not differ?' (Marinella [I60I] I999: 55). But a countercurrent emerged in midcentury in the dialogue by Lodovico Domenichi, La nobiltà delle donne (The nobility of women; Venice I 549/5I). In book I a character (Francesco Grasso, FR.) argues that women are better than men both physically and with respect to their souls because the idea of woman in the mind of God was nobler than the idea of man (Domenichi I 549: bk. I, 9v). In book 2 this claim seems to be overlooked as another character (Lucio Cotto, LU.) argues that if we agree that the soul of man and woman is the same, then the question becomes whether the instruments of the soul are better in one sex or the other (the instruments are both the 'spirits' that mediate psychological and physical activity and the organs of the body) - and so the conversation turns to the superiority of women's bodies (Domenichi I 549: bk. II, 56r-v; Domenichi may have adopted this argument from Vincenzo Maggi's Un brieve trattato dell'eccellentia delle donne [I 545]). Marinella, as we will see, makes use of both these arguments.

\section{I Soul}

First, Marinella asserts that the souls of women are better than those of men, returning to the notion of the soul as an idea in the mind of God. She 
acknowledges the influence of the philosophical tradition according to which the unity of the species requires the identity of the soul in men and women, saying if we speak as philosophers, we will say that man's soul is equally noble to woman's because both are of the same species and therefore of the same nature and substance'. ${ }^{4}$ But she diverges from that tradition: 'I do not agree with this opinion. ... I would say that women's souls were created nobler than men's, as can be seen from the effect they have and from the beauty of their bodies' (Marinella [I60I] I999: 55). ${ }^{5}$ This is because, she says, it is possible that within the same species some souls are nobler than others 'from birth', citing Peter Lombard 2007-10 (Sentences 2.32). Marinella insisted that God, as the efficient or productive cause of women, was able to bestow on them a soul that is superior to that of men: 'Among the many kinds of animals and living things, for example, some are more and some less perfect. All, however, depend on the same cause [i.e., God]. If this is the case, as in truth it is, why should not woman be nobler than man and have a rarer and more excellent Idea than he?' (Marinella [I60I] I999: 53; I have modified the translation). ${ }^{6}$

But this is not to deny the sameness of the rational soul in men and women. In referring to the 'many kinds of animals and living things' Marinella is not arguing that men and women belong to different natural kinds. That is, she is not disputing the identity of the rational soul, but rather suggesting that God is free to assign a more excellent Idea (or soul) to some of the individuals in a species. Later in the treatise she claims to have shown that 'women have the same rational souls as men', and yet that those souls are 'still nobler', (quelle hanno la medesima anima ragioneuole, che ha l'buomo, come di sopra ha mostrato chiaramente, et anco piu nobile [Marinella I60I: 37]). On Marinella's view, then, two persons will have the same species of soul, and yet one might be better than the other. This is probably a claim about differences in degree of worth: men and women have the same kind of rational soul, but those of women have a superior degree of nobility. As we will see, however, Marinella also thinks that certain features of the female body support the operations of the soul in ways that make women superior.

The evidence Marinella offers for the greater nobility of women's souls is the beauty of their bodies. To understand why beauty would constitute evidence for this claim, we need first to recognize that it was the received view of the time that women are more beautiful than men (for an extended discussion in dialogue form of the beauty of women and its moral implications see Agnolo Firenzuola's Dialogo delle Bellezze delle Donne [On the Beauty of Women (I548) I992], complete with geometrical drawings). Marinella is quite explicit about this: 'I say

\footnotetext{
${ }^{4}$ Se noi la prima parte, ciò è l'anima della donna consideriamo, senza dubbio se con Filosofi noi uogliamo parlare, diremo, ch'è tanto nobile l'anima de'maschi, come quella delle donne; percioche l'una, e l'altra sono d'una medesima spetie \& per consequenza della medesima sostanza, \& natura'.

5 'Io direi che l'anime delle donne fossero nella lor produttione via piu nobili di quelle de gli huomini; si come da gli effetti, \& dalla bellezza del corpo si può vedere'.

${ }^{6}$ 'Come nella diversità de gli animali, animanti, et misti. Tra quali alcuni piu perfetti, et altri meno perfetti sono. tutti però dipendenti da una istessa causa. Se adunque cosi è, come veramente è; perche non potrà essere la donna piu nobile dell'huomo, hauendo ella piu rara, et eccellente Idea, di lui, come dalla natura sua manifestamente si puo conoscere'.
} 
that compared to women all men are ugly' (Marinella [I60I] I999: 63). The beauty of women is caused by the soul (58); it is the effect of 'a grace or splendor proceeding from the soul as well as from the body' (la bellezza sia una gratia, ò splendore resultante dall'anima, et dal corpo,57). That is, the physical beauty of women constitutes a demonstration of the superiority of their souls. Marinella is writing in a Platonist tradition that took the attributes of particular sensible beings to be caused by their participation in eternal and immaterial forms. Women, on this view, are beautiful because they participate in the form of the Beautiful itself. On Marinella's account, this form is divine: 'Divine beauty is . . . the first and principal cause of women's beauty' ( $E$ adunque primiera, et principal cagione la bellezza diuina della belià donnesca,6o), and 'external beauty is the image of divine beauty' (Pulchritudo exsterna est duince pulchritudinis imago)-a view she attributes to 'Platonists' (58; she mentions among others in this chapter Plato, Plotinus, Ficino, and Ebreo, although she quotes from Ficino's letters. On beauty having its source in God see Ficino [(1484) I944], Commentary on Plato's Symposium, v. 6, I75). The causal sequence is then: divine beauty is transmitted to the souls of women by means of an idea in the mind of God, and that beauty of the soul is manifested in the bodies of women, causing them to appear beautiful to the senses. Citing Leone Ebreo (a contemporary Platonist), she says 'the corporeal beauty which shines in bodies is a shadow and image of incorporeal beauty' (la bellezza corporea ̀̀ un'ombra, et una imagine della bellezza incorporea, che risplende ne corpi, 58-59). The beauty of women is thus a manifestation, but not a cause, of their superiority. (For more on the importance of beauty in Marinella's treatise, see Shapiro 2013, and Broad and Green 2009.)

\subsection{Body}

Thus, the first cause of the superiority of women is the soul, but there is a second, physical cause, residing in the temperature of the female body, which Marinella construes as an instrument of the soul in a way reminiscent of Domenichi's character Lucio Cotto, mentioned above. This argument is important because it makes clear that even if one were to maintain (contra Marinella) that in principle the souls of men and women are the same in all respects, one might still contend that in their operations women's souls are better. Marinella accepts Aristotle's claim, still embraced by many in the seventeenth century, that men are hotter than women (the view was not universal, and Plutarch's representation of the dispute was influential through the Renaissance; see Moralia 650a-65 Ie for a summary of arguments on both sides). But she rejects the implications that were supposed to follow from that claim, in particular the idea that a cooler temperature is a defect (in the Generation of Animals at 4.I 766a3 I-7 Aristotle makes clear that the capacity and incapacity for concoction that characterize the sexes are produced by differences in heat, and at Generation of Animals 4.6775 I4-I6 he emphasizes that the coldness of the female is a defect).

Even among the pro-woman authors, it is not unusual to find the admission that the coldness of women makes them intellectually poorer than men. For example, the author Galeazzo Flavio Capra, in his treatise Delle Eccellenza e Dignità delle Donne 
(On the excellence and dignity of women [ I 525 ] I988), concedes that women will be less quick-witted than men, while claiming that the heat of men's bodies, by giving rise to irrational desires and passions, makes them morally worse and so less practically wise because practical wisdom requires that one have one's passions under the control of reason (Capra [1525] I988: 75). Moderata Fonte also suggests in her dialogue Il merito delle donne ([ı600] I988; The Worth of Women [I600] I997), that the physiology of women makes them more apprehensive, more credulous, and more easily swayed. The character Corinna says that the explanation for this lies in women's natural disposition and complexion, which is, as all learned men agree, cold and phlegmatic' (Fonte [r600] I997: 83). ${ }^{7}$

Marinella, however, turns the cooler temperature characteristic of women into a virtue (for a discussion of Marinella's physiological argument and its sources in the sixteenth century, see Deslauriers 20I7). She denies that women are cold in absolute terms while conceding that they are cooler than men, and she argues that the relative coolness of women's bodies makes them better both intellectually and morally. Higher heat does not 'serve the tasks of the soul', (seruire alle operationi dell'anima) but 'it is good in a certain amount and in a suitable proportion, as that of woman. Therefore Aristotle's explanation that men are nobler than women because hotter is invalid' (Marinella [I60I] I999: I30). ${ }^{8}$ The soul on Marinella's account uses heat as an instrument but can only use it if it is 'soft and benign, and does not exceed a certain temperate degree' (un dolce, et benigno [calore], che non ecceda una certa mediocrità), and so she concludes that the heat of the male is ill-suited for 'all the operations of the soul, speculative, practical and moral' (tutte le operationi dell'anima speculatiue, prattiche, et morali (Marinella I60I: I35). Although Marinella does not use the term 'spirits' in the physiological sense here or elsewhere in her polemic, given the sources she cites it is likely that she understood heat and cold to be manifest in, and be conveyed by, spirits as the instruments of the soul. On Marinella's view, a hot and dry constitution of the sort she attributes to men 'causes and produces an infinite number of ill effects, such as more passionate appetites and uncontrolled desires, that a moderate heat does not provoke' (Marinella I60I: I36; my translation). 9 Those ill effects are both moral (the excessive appetites and desires) and intellectual (weakening of the activities of speculative and practical reason). So not only is the soul of a woman nobler in degree than a man's, but the constitution or complexion of her body renders the activities of her soul superior to those of his soul.

\section{Buffet}

Marguerite Buffet, working at the end of the seventeenth century in France, was writing in a different phase of the querelle des femmes, one in which pro-woman

\footnotetext{
7 'Io non credo . . . che proceda da altro rispetto, salvo che dalla nostra natural disposition, e complessione, laqual per esser, come affermano tutti I Savi in questa materia, fredda, e flemmatica'.

${ }^{8} \mathrm{Ma}$ [il calore è] bene in un certo grado, et proportione conueniente, come quello della donna. Onde non uale la ragione d'Aristo, sono i maschi più caldi delle Donne'.

9 'Il calore aggiunto con la siccità è grande, et trapassa la mediocrità: eccedendo adunque cagiona et produce infiniti vitiosi effetti, come appetiti piu ardenti, et voglie piu sfrenate, che non eccita il temperato calore'.
} 
writers were particularly concerned with the education of women (see Conley 2002 for an account of the social and intellectual conditions in which Buffet lived). In the Eloges she states her aim in terms of the abilities of women: 'These truths are so well known, [that there have been many illustrious women and] that women can acquire as much ability as men in everything that makes them able, that one cannot argue to the contrary, as I propose to make evident in the course of this discourse'. ${ }^{\text {Io }}$ To show that women can acquire learning and virtue first requires Buffet to demonstrate that they have the necessary capacity of soul.

\section{I Soul}

Poulain de la Barre in De l'égalité des deux sexes: Discours physique et moral où l'on voit l'importance de se défaire des préjugés (On the equality of the two sexes: A physical and moral discourse in which one sees the importance of dismantling prejudices, I673) famously said that the mind has no sex ('on peut conclure qu'il [l'esprit] n'a point de Sexe' [Poullain de la Barre I673: I Io]), but he was not the first. Five years earlier Buffet had written:

It is certain that woman is as close to God as man, whether we consider one sex or the other, and whether in relation to nature or grace. Woman as well as man has the advantage of having been created in the image of the Divinity with respect to the soul, in its unity and in its three noble faculties-understanding, will and memory. Souls having no sex, it follows as a consequence that the beauty of the spirit knows no difference between man and woman, and that this beauty is the prerogative of one and the other sex. (Buffet I668: I99-200) ${ }^{\text {II }}$

Her claim in this passage is that the soul, both as a whole and with respect to its individual faculties, is identical in men and women. Buffet's reference to the soul 'as a whole' (dans son unité) suggests an entity that encompasses multiple faculties, but since the 'three noble faculties' in question are understanding, will, and memory (l'entendement, volonté, memoire), all of which belong to reason, it is clear that the claim concerns the rational soul and its capacities. Buffet's list of noble faculties corresponds to Augustine's list of the three faculties that constitute the rational soul (memoriam, intellegentiam, voluntatem), unique to human beings (Augustine I948 De Trinitate: X. I I [I7]). We should note, however, that because this conception of the rational soul includes the will, it has a component

10 'Ces veritez sont si connues que les femmes peuvent avoir autant d'habilité que les hommes, en tout ce qui les rend habiles, qu'on ne peut rien opposer au contraire, comme je pretens faire voir par la suite de ce discours'.

II 'Il est certain que la femme a autant de rapport avec Dieu que l'homme, soit que nous considerions l'un et l'autre sexe dans la nature \& dans la grace: la femme aussi bien que l'homme a cet avantage d'avoir esté creée à l'image de la Divinité: quant à l'ame, qui dans son unité \& dans ces trois nobles facultez, l'entendement, volonté \& memoire. Les ames n'ayant point de sexe, il s'ensuit par consequent que la beauté de l'esprit ne connoist point cette difference d'homme \& de femme, \& qu'elle est sans difficulté l'apannage de l'un \& de l'autre sexe'. Translations of Buffet throughout are my own. 
that is morally evaluable insofar as it is responsible for decisions and necessary for self-governance.

Buffet distinguishes in this passage between women viewed as the recipients of God's grace and women viewed as natural beings and argues that in both respects they have the same souls as men. The point is important; not only do women have the same prospect of Christian salvation, but they also are members of the same natural kind as men-not only are women created by God just as men are, but the natural capacities of women as persons are also no different than those of men. The implications of this are that the sexes have the same moral worth and the same intellectual capacity. This, of course, is what Buffet intends to show: that the abilities of women are equal to those of men.

Buffet's claim that the souls of men and women are identical is supported by a series of arguments aimed at the antagonists of women (the misogynist literature of the period is extensive; see Rogers I966: chapters 2 and 3 for an overview). The first is that the form of each sex is the same:

We must then look for the difference in their forms, which, having been infused into individuals, cause them to act either (i) by their own powers without any interference from the matter, or (ii) by the disposition of the organs of the subjects that they inform. As for the organs, they are generally similar, and have no sensible differences in either one of the sexes. That is why it is not pertinent to dwell on their particularities.

If the forms of bodies that are intellectual substances are infused into individuals by a superior principle, from which they emanate directly, [these forms] are without doubt equal in power, dignity, and movements. For, to persuade oneself that they are distinguished among themselves, by rank or by priority or otherwise, or even that they are different (or ranked under different) sexes, and that they reproduce themselves or among themselves, as do most material bodies-this would be to commit the circle of Philosophers to an infinite multiplication of beings, superior and inferior, and to imagine the souls and minds were in imagination masculine and feminine in the same way that we distinguish sensible and material things which are ranked under these two kinds, which would be an outrageous error. (Buffet I 668: 220-22) I2 $^{\mathrm{I}}$

I2 'Il faut donc en chercher la difference par leurs formes, lesquelles estant infuses dans les individus, les font agir ou par leurs propres puissances, \& sans aucuns empeschemens de la matiere, ou par la disposition des organes des sujets qu'elles informent. Quant aux organes ils sont generalement semblables, \& n'ont aucunes differences sensibles dans l'un ou dans l'autre sexe. C'est pourquoy il n'y a pas sujet de s'arréter à leurs particularitez.

Si les formes des corps qui sont substances intellectuelles sont infuses dans les individus par un principe superieur, duquel elles soient directement emanées, elles sont sans aucun doute égales en puissance, grandeur \& mouvemens.

Car de se persuader qu'elles soient distinguées entre elles, par ordre ou par degrez de priorité ou autrement, même qu'elles soient differentes ou comprises sous differents sexes, \& qu'elles se multiplient d'elles-mêmes, ou entre elles, comme font la plus-part des corps materiels; ce seroit établir le cercle des Philosophes à une multiplication à l'infiny des existences superieures \& des inferieures, \& s'imaginer que les ames \& les esprits 
These 'forms' are the species forms, or souls, that Buffet characterizes as 'intellectual substances' (substance intellectuelles) in contrast with material substances (Buffet I668: 220-2I). The form allows the human individual both to perform strictly intellectual acts that do not require the body (les font agir . . . par leurs propres puissances, \& sans aucuns empeschemens de la matiere) and also to act in ways that do rely on the parts or organs of the body (par la disposition des organes [Buffet I668: 220]).

The human soul is thus an intellectual substance and the form of the human body. It is, on Buffet's account, infused into the individual by a higher principle (un principe superieur), God, from whom it emanates directly (Buffet I668: 22I). For that reason, she says, all human souls are equal in capacity, dignity, and movement (puissance, grandeur, mouvemens). Buffet asks us to suppose the contrary of the conclusion. We might imagine that the forms of persons, the rational souls that emanate from God, are different from one another in one of two ways: (i) with respect to their order, degree, or priority (par ordre ou par degrez de priorité ou autrement), or (ii) with respect to sex (comprises sous differents sexes). Each of these possibilities would lead to absurd consequences. If rational souls were different from one another in the first way, there would be an infinite multiplication of kinds of beings, both inferior and superior, with each individual effectively constituting a kind. If forms were different in the second way, so that each had a sex, then souls would have to be material and sensible beings. Buffet believes that both of these consequences will be unacceptable, even repugnant, to all reasonable beings and especially to Christians.

Considering each of these consequences in turns allows us to highlight Buffet's conception of the soul as an intellectual substance. The first consequence is one that follows from the notion of the soul as species form-the possession of a human soul makes one a member of the human species at the same time that it bestows on one a set of capacities. Insofar as we speak of the rational soul, those capacities are intellectual and moral, and membership in humankind depends precisely on those capacities. Buffet is arguing that if the souls that emanate from God into individual persons are different one from another, then persons do not constitute a single human kind, but rather (by hypothesis) an infinite number of kinds. That is, the unity of the human essence depends on the identity of the rational soul across individuals. If that identity does not obtain, then we are not a single species.

This argument makes clear why Marinella maintained the sameness in kind of the rational soul in men and women even as she argued for the superiority of women's souls: in order to preserve the unity of the species. To maintain that the rational souls of men and women are the same and at the same time that women's souls are better, one might make the case that although the rational souls of men and women are the same in kind, those of women are better in degree of excellence (we have seen that Marinella suggests as much). This would allow one to preserve the unity of the species while asserting the superiority of the soul of woman. Buffet rejects this 
possibility, for reasons, I suggest, that have to do with her understanding of God as the efficient cause of human beings. Where Marinella describes the human soul as an Idea in the mind of God, Buffet describes our souls as 'breaths of God's divinity' (le Dieu .. . que nos ames soint des soufles de sa Divinité [Buffet I 668: 222]), making reference to Genesis 2:7-8, where we are told that God breathed life into the first man. Given Buffet's reliance on Augustine, it is likely that she is referring to the passage in his De Genesi ad Litteram where he engages in a debate concerned with Genesis 2. 7-8 (Augustine I894). The question is whether God or man was the source of the soul of woman and future generations. Augustine interprets the passage as suggesting that God breathed life not only into the first man but also into the first woman, and hence that her soul too is a direct emanation from God. The point is that if each of our souls is a puff of God's breath, and God's breath is homogeneous, then we should expect our souls to be the same not only in kind but also in degree of nobility.

Buffet's discussion of the second consequence indicates that she, like Marinella, understood God to be the efficient cause of every human being, and not only of the first. The second consequence of asserting that human souls might differ from one another follows if we suppose that the souls of men and women are different in the particular sense that they are sexed or sexually different. The consequence is twofold. First, it would imply that the soul itself can have a sex, as though it were an animal or a material and sensible being, ${ }^{13}$ which would be an outrageous error (une erreur bien extravagante, Buffet I668: 222). Her point seems to be that to assign a sex to a soul is to make a category error, in supposing that an attribute that can only belong to a material being might be transposed onto an immaterial being. Second, supposing that souls are sexually differentiated is an attractive idea only if we assume that the generation of the souls of humans occurs together with the generation of their bodies and as a natural phenomenon in the same way. The passage from Genesis mentioned above, and Augustine's interpretation of it, are again pertinent. If we allow that the rational souls of all human beings, from the first and in all subsequent generations, emanate from God, then it is absurd to suppose that the intellects of men and women should be sexually distinguished in any way. Just as God breathed life into the first man and woman, so too $\mathrm{He}$ (and not the parents of an infant) is the origin of the rational soul in every subsequent human being.

\subsection{Body}

If, then, Buffet argues for the sameness of the rational soul in men and women, how does she arrive at the conclusion that women are superior to men? On the one hand, she asserts a fundamental sameness in physical as well as in psychological makeup. Buffet asks whether women are 'formed and composed' from the same principles and elements as men (Buffet I668: 219). By 'principles and elements' it is clear that she means the material constituents from which men and women are

\footnotetext{
${ }^{13}$ 'Les ames \& les esprits seroient imaginairement en masculin \& en feminin comme nous distinguons les choses sensibles of materielles qui sont sous ces deux genres'.
} 
composed. While the sexes may differ from one another in having more or less of a given material, those materials are no different in kind in men and women. Moreover no one, she says-not even the antagonists of women-denies this (Buffet I668: 219). But not only are the materials that compose the human body the same in men and women; on her account it is also true that the organs of the body are generally similar and have no perceptible differences (n'ont aucunes differences sensibles dans l'un ou dans l'autre sexe [Buffet I668: 220]). That is, Buffet denies sexual difference not only at the level of material composition but also at the level of morphology; the vast majority of the parts and organs of the human body are the same in both sexes.

While maintaining that the material composition and the morphology of men and women are either identical or very similar, Buffet argues for the superiority of women on the basis of their physiology. She acknowledges and distinguishes two kinds of bodily difference in the sexes, both emphasized by the antagonists of women, while insisting that these either make no difference or demonstrate the superiority of women. Those antagonists point out that there are differences in the morphology of the organs related to reproduction in men and women and different movements in the bodies of the two sexes insofar as they carry out reproductive tasks. To this Buffet replies that 'it is necessary that there should be some dissimilarity given that the sexes are destined by nature for different ends in the maintenance and preservation of the species, but that has no bearing on the actions that depend on the will' (Buffet I668: 224). ${ }^{\mathrm{I} 4}$ This response supports her claim that the rational soul (which, recall, includes the will) has no sex; she says 'The faculties of the soul of one sex and the other are all equal; otherwise, their souls and minds would be dissimilar, contrary to what has been demonstrated above' (Buffet I668: 224-25). ${ }^{15}$ Whatever differences there are between men and women in the procreation of offspring, reproductive activities are not initiated by the will and so have no bearing on it or indeed on any aspect of the rational soul. Buffet is suggesting that any bodily differences that do not impact on the rational activities of a person are philosophically insignificant.

The adversaries of women claim that there is a second difference in the bodies of men and women. Buffet describes their position:

[They believe] that the ventricles, the cranial sutures, and the brains of women are smaller and more compressed than men's, and that as a result they [the ventricles] are filled more readily (because there is very little evaporation) with bitter, cloudy, prickling humors that excite the nerves and membranes of women more quickly and violently, because of the gripping and compression of the sagittal and coronal sutures,

\footnotetext{
${ }^{\mathrm{I}} 4$ 'Comme c'est une necessité qu'il ait quelque dissemblance, à cause qu'ils sont destinés par la nature à differens effets pour l'entretien of conservation des especes, que cela ne fait rien pour les actions qui dependent de la volonté'.

${ }^{1} 5$ 'Les facultez de l'ame de l'un \& de l'autre sexe étant toutes égales; autrement les ames \& les esprits seroient dissemblables, contre ce qui est demontré cy-devant '.
} 
and this is what transports them [women] so often to capricious and impulsive movements. (Buffet I 668: 225-26) ${ }^{\mathrm{I} 6}$

These claims were probably formulated in response to a debate about purported sexual differences in cranial sutures in the sixteenth and seventeenth centuries (see Stolberg 2003: 284), which had its origin in a passage in Aristotle's History of Animals: 3.7 5 6 aI5-20 in which he claims that men have three cranial sutures whereas women only have one (see also History of Animals I. 7 49 I b2-6). Buffet accepts the anatomical and physiological claims of the adversaries she mentions here, but responds that these features of women's bodies, far from being defects, render them superior to men. Her reasoning begins with the assertion that the 'spirits and humors' of men, because they are incomparably heavier than those of women, are moved and agitated only with difficulty (Buffet I668: 226; Buffet, following custom, uses the term 'l'esprit' to mean 'mind' and 'les esprits' to refer to the spirits that are the instruments of the soul). The best 'essences', including humors, are those that evaporate quickly, dissipating and disappearing immediately into the air unless the containers and the vessels that hold them are tightly closed. For this reason, nature in its wisdom strongly compressed and tightened the sutures of the skulls of women, especially the coronal suture, so that women's skulls are more retentive of humors and spirits (227). All composites are better insofar as their parts act more quickly, and machines are more admirable when their constituent parts operate at a higher speed and their springs are faster; in general, anything, whether artifact or natural entity, is less valued for its effects or actions when its parts act more slowly. So, insofar as women's spirits and humors are quicker than men's it follows that they are better. As confirmation of her argument that a larger head is not an advantage, Buffet points out that since we do not think that donkeys, buffalo, or oxen have more brains or intellect than men, despite having large heads, it is absurd that men should pride themselves on the size of their bodies or the magnitude of their heads (228).

This argument clearly draws on three sources: (i) the debate among anatomists about sexual differences in cranial structure and brain size (see MacLean I980 for a discussion of the influence of medicine, anatomy and physiology on Renaissance understandings of sexual difference), (ii) a notion of bodily humors as equivalent to spirits and the instruments of the soul, operating to mediate its relation to the body (see Bono I984 for a history of this sense of spirits), and (iii) a Cartesian conception of the human body as a machine (see Hatfield 2007).

Buffet in fact makes two claims of superiority for women. The first is intellectual. She says that we can conclude with certainty that women in general have livelier minds than men (que les femmes on plus de vivacité d'esprit que les hommes), which is manifest in many domains (228). This claim clearly follows from her

\footnotetext{
${ }^{16}$ 'Quant à ce que les adversaires disent que les ventricules, les sutures des testes, \&́ cerveaux feminins sont plus petits, \& plus serrez que ceux des mâles, \& qu'ils se remplissent par consequent plus facilement \& sans presque aucune évaporation des humeurs acres, fuligineuses \& mordiquantes, qui piquent plus promptement \& plus violamment les nerfs \& les membranes des femmes, à raison des étressissemens \&o compressions des sutures capitalles \& coronalles, \& que c'est ce qui les transporte si souvent aux mouvements fantasques \& precipitez, ausquels on les voit presque toûjours'.
} 
anatomical assertions. Not only do women have livelier humors in the first place, but those humors are contained and thus continue to operate within the body since they are prevented from escaping by means of the close sutures of the cranium. So there is, on her account, a physiological basis for the intellectual excellence of the female sex, compatible with the sameness of souls. If souls require certain instruments for some of their operations, and if women have better instruments, then women are intellectually better even if their rational souls do not differ from those of men.

The second point of superiority is moral. Buffet writes:

It is always true that women have a greater share of the gifts of Heaven and of nature than men: they are more pious, they are more reliable in [keeping] their promises, more constant and stronger with respect to what they love; they surpass men in beauty and in all perfections by a great measure-this is sufficiently demonstrated as much by the most adept authorities and the most gallant men as by all the reasons cited above. $(230-3 \mathrm{I})^{\mathrm{I} 7}$

Despite, however, the mention of 'reasons cited above' there does not seem to be an argument in Buffet's Eloge for the assertion in this passage that women are more pious, more reliable, and more constant. It may be that Buffet assumes that this follows from the intellectual superiority of women or that it is self-evident because observable. But the mention here of the beauty of women that surpasses that of men suggests an implied argument of the sort we have seen in Marinella's treatise: if women are more beautiful than men, this is a physical manifestation of a moral superiority. Notice, however, that Buffet cannot intend that in just the same way as Marinella, since Marinella has stipulated that women's souls are better than men's and argued that their bodies are more beautiful because they are manifestation of that more beautiful soul. Since Buffet denies that there are any differences in the minds of men and women, she does not argue that the beauty of women is a manifestation of the soul, but rather treats it as a 'gift of heaven', perhaps mediated by the physiology characteristic of women.

\section{Conclusion}

There are striking similarities in the structure of the arguments formulated by Marinella and Buffet for the worth of women: a commitment to the sameness of the rational soul in men and women, an attempt to demonstrate the advantages of certain characteristic features of the female body, and the conclusion that women are ultimately superior to men in intellect and morals. The differences in the details of their arguments are, however, significant. With respect to the soul, two points are most important. First, while they agree that the rational faculty is the

\footnotetext{
${ }^{17}$ 'Il est constant que les femmes ont un plus grand partage des dons du Ciel \& de la nature que les hommes: elles ont plus de pieté, elles sont plus fidelles dans leurs promesses, plus constantes o plus fortes en ce qu'elles aiment; elles surpassent de beaucoup les hommes en beautez, of en toutes perfections; ce qui est suffisamment prouvé, tant par les authoritez des plus habiles, \& des plus galants hommes, que par toutes les raisons dites cy-devant'.
} 
same in both sexes, their conceptions of reason as a faculty differ. Marinella understands reason to comprise speculative and practical reason, following an Aristotelian division that would place memory in a distinct faculty (imagination) and would not recognize 'will'. Buffet, by contrast, divides reason into understanding, will, and memory, following Augustine; the inclusion of will and memory extends the scope of the claim of equality based on shared reason that Buffet defends. Second, as we have seen, Marinella suggests that the rational soul is the same in kind in both sexes, but superior in worth in women, whereas Buffet rejects the idea that there might be any difference either in kind or in degree.

With respect to the body, the differences in the details of their arguments are evident. On Marinella's account, the female body is better because its cooler temperature makes the operations of the soul slower and more deliberate, whereas on Buffet's account the female body is better because the narrowness of the ventricles in the brain and the tightness of the sutures in the cranium produce livelier spirits. Clearly, the physical features they take to be distinctive and significant in making women superior are not the same. Moreover, the effects they ascribe to those features are opposed: women are better because slower or better because quicker. We can deduce how contested the facts of sexual difference were in the seventeenth century, even among people who agreed on the authority of ancient philosophy, the ancient medical traditions, and Christian scripture, from the different representations Marinella and Buffet make of the female body. These divergent accounts of physiology and of reason as a faculty have implications for any account of the interaction of soul and body and hence for any attempt to base claims of the superiority of one sex on such interactions, as do Marinella and Buffet. Elaborating those implications is work that remains to be done.

The similarity of Marinella's and Buffet's arguments demonstrates that the strategy of following an equality claim with an argument for the superiority of women persisted among pro-woman authors throughout the seventeenth century. Since feminists with different notions of reason, different analyses of physiological differences between the sexes, and different accounts of the effects of physiology on rational activities were able to adopt that strategy, it was plainly a flexible structure, adaptable to a variety of intellectual contexts. The longevity of the strategy also suggests its usefulness. Even while some seventeenth-century authors (Gournay and Poulain de la Barre most prominently) argued for equality tout court, some pro-woman writers believed that metaphysical equality, of the sort established by claims of a common faculty of reason shared by men and women, was insufficient to gain for women the liberty, education, and political agency they sought.

MARGUERITE DESLAURIERS

MCGILL UNIVERSITY

marguerite.deslauriers@mcgill.ca

\section{References}

Agrippa, Henricus Cornelius. ([I 529] I990) De nobilitate et praecellentia foeminei sexus. Edited by Roland Antonioli and Charles Béné, translated by Odette Sauvage. Geneva: Droz. 
Agrippa, Henricus Cornelius. (I 529 [1996]) Declamation on the Nobility and Preeminence of the Female Sex. Translated and edited by A. Rabil Jr. Chicago: University of Chicago Press.

Angenot, Marc. (1977) Les Champions des Femmes. Montréal: Presses de l'Université du Québec. Augustine of Hippo. (r948) De Trinitate. In L. Arias (ed.), Corpus Christianorum, Series Latina (CCL). Turnhout: Brepols.

Augustine of Hippo. (I894) De Genesi ad Litteram. In J. Zycha (ed.), Corpus Scriptorum Ecclesiasticorum Latinorum (CSEL) 28.I. Vienna: Academiae Litterarum Caesariae Vindobonensis.

Bono, James J. (I984) 'Medical Spirits and the Medieval Language of Life'. Traditio, 40, 9I-I30.

Broad, Jacqueline. (20I2) 'Impressions in the Brain: Malebranche on Women, Women on Malebranche'. Intellectual History Review, 22, 373-89.

Broad, Jacqueline, and Karen Green. (2009) A History of Women's Political Thought in Europe, I400-I700. Cambridge: Cambridge University Press.

Buffet, Marguerite. (I668) Nouvelles observations sur la langue française; où il est traitté des termes anciens et inusitez et du bel usage des mots nouveaux avec les Éloges des Illustres Sçavantes Anciennes et Modernes. Paris: Jean Cusson.

Cadden, Joan. (1993) Meanings of Sex Difference in the Middle Ages: Medicine, Science and Culture. Cambridge: Cambridge University Press.

Capra, Galeazzo Flavio. (I 525 [1988]) Delle eccellenza e dignità delle donne. Edited by M. L. Doglio. Europa delle Corti, Centro studi sulle società di antico regime, Biblioteca del Cinquecento. Rome: Bulzoni editore.

Castiglione, Baldassare. (1959) The Book of the Courtier. Translated by Charles S. Singleton. New York: Doubleday.

Castiglione, Baldassare. (1965) Il libro del Cortegiano. Edited by Giulio Preti. Torino: Einaudi.

Conley, John J. (2002) The Suspicion of Virtue: Women Philosophers in Neoclassical France. Ithaca, NY: Cornell University Press.

Descartes, René. ([1637] 1954) Discours de la Méthode, avec introduction et notes. Edited by É. Gilson. Paris: Vrin.

Deslauriers, Marguerite. (2017) 'Marinella and her Interlocutors: Hot Blood, Hot Words, Hot Deeds'. Philosophical Studies, I74, 2525-37.

Domenichi, Lodovico. (I 549) La Nobiltà delle donne. Venice: Giolito di Ferrari.

Ducharme, Isabelle. (2003) 'Marguerite Buffet lectrice de la querelle des femmes'. In I. Brouard-Arends (ed.), Lectrices d'ancien régime (Rennes: Presses Universitaires de Rennes), $33 \mathrm{I}-4 \mathrm{O}$.

Ficino, Marsilio. ([1484] I944) Marsilio Ficino's Commentary on Plato's Symposium. Translated and edited by S. R. Jayne. Columbia: University of Missouri Press.

Firenzuola Agnolo. ([I 548] I992) On the Beauty of Women; Dialogo delle Bellezze delle Donne. Translated and edited by K. Eisenbichler and J. Murray. Philadelphia: University of Pennsylvania Press.

Fonte, Moderata [Modesta Pozzo]. ([ı600] I988) Il merito delle donne. Edited by A. Chemello. Venice: Eidos.

Fonte, Moderata. ([I600] 1997). The Worth of Women. Translated and edited by Virginia Cox. Chicago: University of Chicago Press.

Fonte, Moderata ([I $58 \mathrm{I}]$ 2006). Floridoro: A Chivalric Romance. Translated by Julia Kisacky, edited by Valeria Finucci. Chicago: University of Chicago Press.

Gottlieb, B. (I997) 'The Problem of Feminism in the Fifteenth Century'. In R. Blumenfeld-Kosinski (ed.), The Selected Writings of Christine de Pizan (New York: Norton), 274-96.

Gournay, Marie de. (2002a) Oeuvres complètes. 2 volumes. Edited by J.-C. Arnould, E. Berriot, C. Blum, A. L. Franchetti, M.-C. Thomine, V. Worth-Stylianou. Paris: Honoré Champion.

Gournay, Marie de. (2002b) Apology for the Woman Writing and Other Works. Translated and edited by R. Hillman and C. Quesnel. Chicago: University of Chicago Press.

Harth, Erica. (1992) Cartesian Women. Ithaca, NY: Cornell University Press.

Hatfield, Gary. (2007) 'The Passions of the Soul and Descartes's Machine Psychology'. Studies in History and Philosophy of Science, 38, I-35.

Hoffman, Paul. (1977). La Femme dans la pensée des lumières. Paris: Ophrys. 
Jordan, Constance. (1990) Renaissance Feminism: Literary Texts and Political Models. Ithaca, NY: Cornell University Press.

Kelly, Joan. (I982) 'Early Feminist Theory and the Querelle des Femmes, I400-1789'. Signs, 8, 4-28.

King, M. (199I) Women of the Renaissance. Chicago: University of Chicago Press.

Kolsky, Stephen. (200I) 'Moderata Fonte, Lucrezia Marinella, Giuseppe Passi: An Early Seventeenth-Century Feminist Controversy'. The Modern Language Review, 96, 973-89.

Lloyd, Genevieve. (1984) The Man of Reason: 'Male' and 'Female' in Western Philosophy. London: Methuen.

Lombard, Peter. (2007-10) The Sentences. Translated by Giulio Silana. Toronto: Pontifical Institute of Medieval Studies.

Maggi, V. ( 1545 ) Un brieve trattato dell'eccellentia delle donne. Brescia: Damiano de Turlini.

Malebranche, Nicolas. ([1674] 1962) Recherche de la Verité. Edited by G. Rodis-Lewis and H. Gouhier. Paris: Vrin.

Marinella, Lucrezia. (I60I) La nobiltà et l'eccellenza delle donne co' diffetti et mancamenti de gli uomini. Venice: Battista Ciotti.

Marinella, Lucrezia. ([160I] 1999) The Nobility and Excellence of Women and the Defects and Vices of Men. Translated by Anne Dunhill. Chicago: Chicago University Press.

MacLean, Ian. (1980) The Renaissance Notion of Woman: A Study in the Fortunes of Scholasticism and Medical Science in European Intellectual Life. Cambridge: Cambridge University Press.

Poulain de la Barre, François. (I673) De l'égalité des deux sexes: Discours physique et moral, où l'on voit l'importance de se défaire des Préjugez. Paris: Jean du Puis.

Reuter, Martina. (2019) 'The Gender of the Cartesian Mind, Body, and Mind-Body Union'. In M. Reuter and F. Svensson (eds.), Mind, Body and Morality: New Perspectives on Descartes and Spinoza (New York: Routledge), 37-58.

Rogers, Katharine. (1966) The Troublesome Helpmate: A History of Misogyny in Literature. Seattle: University of Washington Press.

Schiebinger, Londa. (1989) The Mind Has No Sex? Women in the Origins of Modern Science. Cambridge, MA: Harvard University Press.

Shapiro, Lisa. (2013) 'The Outward and Inward Beauty of Early Modern Women'. Revue Philosophique de la France et de l'Étranger, 203, 327-46.

Stolberg, Michael. (2003) 'A Woman Down to Her Bones: The Anatomy of Sexual Difference in the Sixteenth and Early Seventeenth Centuries'. Isis, 94, 274-99. 